\title{
FAKTOR-FAKTOR YANG MEMPENGARUHI MINAT MAHASISWA BERWIRAUSAHA (STUDI KASUS MAHASISWA PENDIDIKAN EKONOMI YANG MENGIKUTI MATA KULIAH PRAKTIKUM KEWIRAUSAHAAN FAKULTAS EKONOMI UNIVERSITAS NEGERI MEDAN)
}

\author{
Putri Kemala Dewi Lubis \\ Fakultas Ekonomi, Universitas Negeri Medan
}

\begin{abstract}
Abstrak
Penelitian ini bertujuan untuk mengetahui pengaruh kepribadian dan lingkungan keluarga terhadap minat berwirausaha pada mahasiswa Jurusan Pendidikan Ekonomi Fakultas Ekonomi Universitas Negeri Medan. Penelitian ini dilakukan dengan metode kuesioner. Sampel penelitian ini adalah mahasiswa Semester Enam Jurusan Pendidikan Ekonomi Universitas Negeri Medan yang mengikuti kuliah praktikum kewirausahaan sebanyak 60 orang. Jenis datanya adalah data primer dengan teknik pengumpulan data kuesioner. Teknik analisis data menggunakan analisis regresi berganda. Hasil penelitian menunjukkan bahwa: kepribadian, dan lingkungan keluarga secara simultan tidak berpengaruh signifikan terhadap aktivitas berwirausaha mahasiswa Universitas Negeri Medan $(8,07 \%)$. Secara parsial kepribadian tidak berpengaruh signifikan $(2,24 \%)$. Serta lingkungan keluarga berpengaruh signifikan ( $1,58 \%)$. Berdasarkan hasil penelitian, maka dapat disimpulkan bahwa kepribadian dan lingkungan keluarga secara simultan berpengaruh positif dan signifikan terhadap aktivitas berwirausaha mahasiswa. Secara parsial kepribadian berpengaruh positif dan signifikan terhadap aktivitas berwirausaha mahasiswa, sedangkan pendidikan kewirausahaan dan lingkungan keluarga berpengaruh positif namun tidak signifikan terhadap aktivitas berwirausaha mahasiswa.
\end{abstract}

Keywords: Kewirausahaan, minat, kepribadian, lingkungan keluarga 


\section{PENDAHULUAN}

Pengangguran merupakan masalah yang menjadi tantangan besar bagi Pemerintahan dan masyarakat Indonesia yang berdampak pada masalah-masalah lain seperti kemiskinan dan kesenjangan sosial. Memasuki pasar bebas dan persaingan global yang kian ketat, menuntut masyarakat khususnya yang berada pada usia produktif untuk memiliki kualitas individu yang aktif dan kreatif agar mampu bersaing secara kompetitif untuk mengurangi angka pengangguran yang ada. Tidak dapat dipungkiri bahwa Indonesia mengalami keterbatasan kesempatan kerja bagi lulusan perguruan tinggi dengan semakin meningkatnya pengangguran intelektual. Angka lulusan perguruan tinggi yang setiap tahun bertambah jumlahnya, namun lapangan pekerjaan yang tersedia semakin sempit. Pihak instansi dan swasta tidak dapat diharapkan sepenuhnya, karena jumlah permintaan dan yang ditawarkan dari tenaga kerja sudah tidak berimbang dengan jumlah angka lulusan serta daftar antrian para pencari kerja. Meningkatnya jumlah pengangguran tersebut disebabkan karena mulai sempitnya lapangan pekerjaan, sehingga menyebabkan semakin banyaknya lulusan perguruan tinggi yang menganggur karena tingkat persaingan dalam melamar pekerjaan semakin tinggi.

Hal yang paling mendorong seseorang untuk memasuki karir wirausaha adalah adanya (1) personal attributes dan (2) personal environment. Kepribadian yang dimiliki seseorang dapat memikat orang lain untuk simpati padanya, tertarik dengan pembicaraan dan terkesima olehnya. Wirausahawan yang memiliki kepribadian seperti itulah yang seringkali berhasil dalam menjalankan usahanya (Alma, 2011:78). Selain kepribadian yang disampaikan oleh Alma tersebut, penelitian yang dilakukan Mopangga (2014) menjelaskan untuk mengatasi permasalahan terkait aktivitas wirausaha yaitu dengan memperbanyak frekuensi praktik kewirausahaan, melaksanakan pembelajaran kontekstual secara periodik, menyediakan dan melengkapi fasilitas di kampus. Selain dua faktor tersebut, lingkungan keluarga dianggap sebagai faktor yang seyogyanya dapat mempengaruhi keberhasilan usaha. Pada dasarnya keluarga merupakan tempat pendidikan pertama yang diterima oleh anak. Perawatan orang tua yang penuh kasih sayang dan pendidikan tentang nilainilai kehidupan, baik agama maupun sosial budaya yang diberikannya merupakan faktor yang kondusif untuk mempersiapkan anak menjadi pribadi dan anggota masyarakat yang sehat (Yusuf, 2009:37). Seringkali terlihat bahwa ada pengaruh dari orang tua yang bekerja sendiri, dan memiliki usaha sendiri cenderung anaknya akan menjadi pengusaha pula. Orang tua yang berlaku demikian cenderung mendukung serta mendorong keberanian anaknya untuk berdiri sendiri.

Hipotesis yang digunakan dalam penelitian ini adalah 1. Secara parsial ada pengaruh signifikan kepribadian dan lingkungan keluarga terhadap minat berwirausaha mahasiswa jurusan Pendidikan Ekonomi Universitas Negeri Medan. 2. Secara simultan ada pengaruh signifikan kepribadian dan lingkungan keluarga terhadap minat berwirausaha mahasiswa jurusan Pendidikan Ekonomi Universitas Medan. 


\section{METODE PENELITIAN}

Desain penelitian yang digunakan dalam penelitian ini adalah metode survei. Menurut Sukardi (2008: 193) metode survei merupakan metode paling baik guna memperoleh dan mengumpulkan data asli (original data) untuk mendeskripsikan keadaan. Dalam penelitian ini metode survei dilakukan untuk mengetahui keberlangsungan dari aktivitas berwirausaha mahasiswa Universitas Negeri Medan dengan menggunakan angket sebagai instrumen. Populasi dan sampel dalam penelitian ini menggunakan sampling jenuh yaitu semua anggota populasi digunakan menjadi sampel. (Sugiyono, 2009). Jumlah sampel yang digunakan sebanyak 60 orang mahasiswa semester 6 yang terdiri dari kelas A reguler sebanyak 27 orang dan kelas B sebanyak 33 orang. Metode analisis data menggunakan metode analisis deskriptif. Menurut Sugiyono (2009:147) statistik deskriptif adalah statistik yang digunakan untuk menganalisis data dengan cara mendeskripsikan atau menggambarkan data yang telah terkumpul sebagaimana adanya tanpa bermaksud membuat kesimpulan yang berlaku untuk umum atau generalisasi). Pada penelitian ini analisis statistik deskriptif yang digunakan adalah deskriptif persentase. Analisis ini digunakan untuk mendeskripsikan variaabel aktivitas berwirausaha, kepribadian, dan lingkungan keluarga. Teknik analisis data menggunakan uji normalitas, uji linieritas, uji asusmsi klasik dan analisis regresi linier berganda.

\section{HASIL DAN PEMBAHASAN}

Berdasarkan hasil analisa data maka persamaan regresi linier berganda sebagai berikut : $Y=-\mathbf{5 , 0 1 5}+\mathbf{0 , 4 7 3} \mathrm{X} 1+\mathbf{0 , 3 3 8}$
X2 . Hal ini dapat disimpulkan bahwa jika Variabel Kepribadian (X1) dan variabel lingkungan (X2) nilainya nol, maka minat berwirausaha mahasiwa semester 6 jurusan pendidikan ekonomi Universitas Negeri Medan nilainya sebesar -5,015. Koefisien regresi variabel kepribadian sebesar 0,473, hal ini menunjukkan jika variabel kepribadian mengalami kenaikan $1 \%$, maka minat berwirausaha mahasiwa semester 6 jurusan pendidikan ekonomi akan mengalami kenaikansebesar 47,3\%. Koefisien regresi variabel lingkungan keluarga sebesar 0,338. Hal ini menunjukkan bahwa variabel lingkungan mengalami kenaikan $1 \%$ maka minta berwirausaha mahasiswa semester 6 jurusan pendidikan ekonomi akanmengalami kenaikan sesar 33,8\%.

Pengujian hipotesis yang dilakukan menunjukkan bahwa secara simultan tidak ada pengaruh signifikan kepribadian dan lingkungan keluarga terhadap minat berwirausaha mahasiwa semester 6 jurusan pendidikan ekonomi fakultas ekonomi universitas negeri medan. Hal ini berdasarkan nilai $\mathrm{F}$ hitung $>\mathrm{F}$ tabel $(8,073$ $>3,159)$ maka hipotesis penelitian ditolak. Secara parsial nilai t-hitung lebih kecil dari nilai t-tabel $(2,244>1,672)$ artinya secara parsial ada tidak pengaruh signifikan kepribadian terhadap minat berwirausaha masiswa semester 6 jurusan pendidikan ekonomi fakultas ekonomi universitas negeri medan, dengan demikian hipotesis penelitian ditolak. Untuk variabel lingkungan keluarga secara parsial nilai thitung lebih kecil dari nilai t-tabel $(1,568<$ 1,672) artinya secara parsial ada pengaruh signifikan lingkungan keluarga terhadap minat berwirausaha masiswa semester 6 jurusan pendidikan ekonomi fakultas 
ekonomi universitas negeri medan, dengan demikian hipotesis penelitian diterima.

\section{KESIMPULAN}

Berdasarkan hasil analisis dan pembahasan yang telah diuraikan sebelumnya, maka diperoleh simpulan sebagai berikut: 1 . Tidak ada pengaaruh signifikan kepribadian, dan lingkungan keluarga terhadap aktivitas berwirausaha mahasiswa Universitas Negeri Medan sebesar $8,07 \%$ 2. Tidak ada pengaruh signifikan kepribadian terhadap aktivitas berwirausaha mahasiswa Universitas Negeri Medan sebesar 2,24\% 3. Ada pengaruh signifikan lingkungan keluarga terhadap aktivitas berwirausaha mahasiswa Universitas Negeri Medan sebesar $1,58 \%$.

Saran untuk penelitian selanjutnya agar memasukkan faktor-faktor lain untuk memperluas variabel penelitian di luar variabel independen yang terdapat dalam penelitian ini, sehingga akan didapatkan faktor-faktor apa saja yang mempengaruhi aktivitas berwirausaha mahasiswa secara lebih luas dan ada temuan baru yang lebih kreatif dan inovatif.

\section{REFERENSI}

Ahmad, Nadim dan Richard G. Seymour. 2008. Defining Entrepreneurial Activity: Definitions Supporting Frameworks for Data Collection. Dalam OECD Statistics Working Paper, Volume - No.- Hal.1-15. Sydney: University of Sydney.

Akanbi, Samuel Toyin. 2013. Familial Factors, Personality Traits and Self-Efficacy as Determinants of
Entrepreneurial Intention Among Vocational Based College of Educational Students in Oyo State Nigeria Dalam Journal of The African Educational Research Network, Vol.13 No.2 Hal.66-76. Nigeria: Emmanuel Alayande College of Education.

Alma, Buchori. 2011. Kewirausahaan. Bandung: Alfabeta.

Almeida, Patricia I. L., Gorkan Ahmetoglu, dan Tomas Chamorro Premuzic. 2013. "Who Wants to Be an Entrepreneur? The Relationship Between Vocational Interests and Individual Differences in Entrepreneurship". Dalam Journal of Career Assessment, Volume 22 No.1. Hal 102-112. London: University of London.

Arikunto, Suharsimi. 2010. Prosedur Penelitian Suatu Pendekatan Praktik.

Jakarta: Rineka Cipta.

Basrowi. 2011. Kewirausahaan Untuk Perguruan Tinggi. Bogor: Ghalia Indonesia.

Ghozali, Imam. 2013. Aplikasi Analisis Multivariate dengan Program IBM SPSS 21. Semarang: Badan Penerbit Universitas Diponegoro.

Gujarati, Damodar N. Dan Dawn C. Porter. 2010. Dasar-Dasar Ekonometrika. Jakarta: Salemba Empat. Hartati, Sri, dkk. 2014. "Model of Entrepreneurship Learning in Growing New Entrepreneur (Case Study in Centre of Business Incubator, West Java, Indonesia)". Dalam Journal of Education and Vocational Research, Volume 5 No.4. Hal 
239-246. Bandung: School of Business and Management ITB.

Holland, John L. 2004. Psikologi Pemilihan Karier. Terjemahan Dewa Ketut Sukardi. Jakarta: Rineka Cipta.

Ihsan, Fuad. 2005. Dasar-Dasar Kependidikan. Jakarta: Rineka Cipta. Indratno, A. Ferry. 2012. Membentuk Jiwa Wirausaha. Jakarta: Kompas.

Koch, Lambert T. 2002. Theory and Practice of Entreprenerurship Education. Jerman: Universitu of Wuppertal.

Littunen, Hannu. 2010. Entrepreneurship and the characteristics of the entrepreneurial personality. Dalam International Journal of Entrepreneurial Behavior \& Research, Volume 6, Hal. 295310. Finland: University of Jyvaskyla.

Mopangga, Herwin. 2014. "Faktor Determinan Minat Wirausaha Mahasiswa Fakultas Ekonomi dan Bisnis Universitas Negeri Gorontalo". Dalam Jurnal Trikonomika, Volume 13 No.1. Hal 78-90. Gorontalo: Universitas Negeri Gorontalo.

Morris, Michael H. dan Pamela S. Lewis. 1995. The Determinants of Entrepreneurial Activity. Dalam European Journal of Marketing, Volume 29 No.7. Hal 31-48. Florida: University of Central Florida.

Noekent, Vitradesie dan Sinta Saraswati. 2012. "Laporan Penelitian Hibah Tracer Study". Laporan Peneltian. Semarang: Universitas Negeri Semarang.
Notoatmodjo,Soekidjo. 2003. Pendidikan dan Perilaku

Kesehatan. Jakarta: Rineka Cipta. Purwanto, Ngalim. 2011. Psikologi Pendidikan. Jakarta: Remaja Rosdakarya Sjarkawi. 2008. Pembentukkan Kepribadian Anak. Jakarta: Bumi Aksara.

Slameto. 2010. Belajar dan Faktor-faktor yang Mempengaruhinya. Jakarta: PT. Rineka Cipta.

Sugiyono. 2009. Metode Penelitian

Kuantitatif, Kualitatif dan $R \& D$. Bandung: Alfabeta.

Sujanto, Agus., Halem Lubis, dan Taufik Hadi. 2006. Psikologi Kepribadian. Jakarta: Bumi Aksara.

Sukardi. 2008. Metodologi Penelitian

Pendidikan. Jakarta: Bumi Aksara. 